\title{
Critical food systems education and the question of race
}

COMMENTARY ON RACE AND ETHNICITY IN FOOD SYSTEMS

\author{
David Meek ${ }^{a *}$ \\ University of Alabama \\ Rebecca Tarlau ${ }^{b}$ \\ Stanford University
}

Submitted June 16, 2015 / Published online September 1, 2015

Citation: Meek, D., \& Tarlau, R. (2015). Critical food systems education and the question of race. Journal of Agriculture,

Food Systems, and Community Development, 5(4), 131-135. http://dx.doi.org/10.5304/jafscd.2015.054.021

Copyright (C) 2015 by New Leaf Associates, Inc.

\section{Abstract}

Studies of food systems education have largely avoided questions concerning race. In this commentary, we interrogate the racial assumptions behind certain food systems education projects. Food systems educators are often motivated by a whitened cultural desire to "bring good food to others" and see garden-based learning projects, which seek to instill healthy nutritional behaviors, as the solution to the problem of purported food

a* Corresponding author: Dr. David Meek, Department of Anthropology, University of Alabama; 25a ten Hoor Hall; Mars Spring Road; Tuscaloosa, Alabama 35487 USA; ddmeek@ua.edu

${ }^{\mathrm{b}}$ Dr. Rebecca Tarlau, Postdoctoral Fellow, Stanford University.

\section{Author notes}

Dr. David Meek is a faculty member in the Department of Anthropology, University of Alabama, where he teaches courses surrounding food systems. He theoretically grounds his research in a synthesis of political ecology, critical deserts. We argue that food systems education is in need of a critical intervention. In this commentary, we propose critical food systems education (CFSE) as a theoretical framework, set of pedagogies, and vision for policy that moves beyond teaching students about the food system, and helps them realize their potential to structurally transform it through collective action. The CFSE perspective is theoretically grounded in food justice, food sovereignty, political agroecology, and critical

pedagogy, and food sovereignty. Dr. Meek's research has been funded by the National Science Foundation, Social Science Research Council, and Fulbright Foundation.

Dr. Rebecca Tarlau is a postdoctoral scholar in education at Stanford University, affiliated with the Lemann Center for Educational Entrepreneurship and Innovation in Brazil. She received an M.A. and Ph.D. from the University of CaliforniaBerkeley. Her research focuses on the relationship between states, social movements, and educational reform. Her most recent project was a subnational comparative ethnography of the Brazilian Landless Workers' Movement's (MST). 
pedagogy. The CFSE approach is not merely theoretical, but arises from the examples of grassroots social movements throughout the world that have developed radical forms of food systems education. We highlight this approach using the example of the Brazilian Landless Workers' Movement (MST). The MST opposes a racialized discourse of the "peasantry" as backwards and ignorant. The movement's leaders reject a vision of education that reproduces white modernity, and instead support a vision that advances radical agroecological education programs that train students to be political subjects capable of creating a socially and environmentally equitable food system. The example of the MST underscores the potential of CFSE as a corrective for the food systems education's racialized assumptions.

\section{Keywords}

race, garden-based learning, food systems education, critical food systems education, Landless Workers' Movement, MST, food sovereignty, food justice, agroecology, critical pedagogy

\section{Questioning Race in Food Systems Education: Towards a Transformative Alternative}

A troubling racial narrative increasingly characterizes certain forms of food systems education. The images are ubiquitous. They hang in the hallways of universities, on the doors of local farm-to-table restaurants, and in the promotional materials for numerous nutrition intervention programs, such as First Lady Michelle Obama's Let's Move. African American elementary-school children kneel down beside raised-bed gardens staring with amazement at the succulent vegetables they are growing. These images are frequently paired with statements lamenting the lack of school funding, the number of children receiving free meals, and the paucity of access to fresh produce for socioeconomically disadvantaged students. The nongovernmental organizations and government officials promulgating these projects, like many in the alternative food movement, are motivated by an honest desire to "bring good food to others" (Guthman, 2008).

As critical food scholars point out, the alternative food movement is characterized by an "unbearable whiteness" where its agrarian ideals, such as the importance of "getting your hands dirty" (Guthman, 2008, p. 435), reflects whitened cultural histories and ultimately produces racialized spaces of social exclusion (Slocum, 2007). In spite of the best of intentions, many food education projects falter because they are based in these whitened cultural ideals and agrarian imaginaries. Researchers contribute to this problematic racialized intervention by showing that the environmental attitudes of African American students who participate in garden-based learning increase less than their White counterparts (Waliczek \& Zajicek, 1999). Rather than asking why food education projects do not achieve their purported goals among students of color, we follow Guthman's (2008) lead and question the ideological intentions and racial assumptions of these programs and their proponents.

Food systems projects often serve as a form of problem enclosure, in which a specific definition of a problem determines the understanding of the causes, consequences, and appropriate solutions (Guthman, 2012). In the case of food systems education, the "problem" is frequently defined as food deserts where socio-economically depressed communities presumably have low access to fresh produce. Yet a growing scholarship is challenging the food desert narrative (Boone-Heinonen, GordonLarsen, Kiefe, Shikany, Lewis, \& Popkin, 2011). Lee's (2012) study, for example, shows that in comparison with wealthier neighborhoods, lowincome communities have twice as many fast food restaurants and three times as many convenience stores, but - here's the kicker-surprisingly, almost twice as many large supermarkets per square mile. Focusing on schools, An and Sturm (2012) find no relationship between the types of food that students report eating, their weight, and the types of food available in close proximity to their homes. By framing food deserts as a problem of low access, rather than one of historical and social processes of red-lining, state disinvestment, or racist lending practices, for example, the problem definition produces the conditions for its own intervention: creating school gardens to help instill good 
values and nutritional choices in "at-risk" populations. While its proponents see these programs as redressing socioeconomic inequalities, food systems education is insufficient for helping youth understand the racialized injustices inherent to the current food system, and their capacity to transform them through collective action.

Part of the problem is that despite the burgeoning critical scholarship on race in the alternative food movement (e.g., Alkon \& McCullen 2011; Ramírez, 2015), surprisingly little has focused on education-a strange absence given education's role in maintaining racial and class privilege (Anyon, 1997; Bowles \& Gintis, 1976; Lipman, 2011; Willis, 1977). A notable exception is the work of Allen and Guthman (2006), who explore the increasing neoliberalization of farm-to-school programs. Etmanski's (2012) work also provides a welcome departure, exploring how adult educators in the organic farming movement can engage in anti-racist pedagogy, becoming allies with indigenous movements, and connecting their practice to the rapidly growing food sovereignty movement. The purpose of our commentary is to build on these emerging works in order to transform the dominant discussion about food system education and offer a concrete alternative.

Education, we believe, is both a natural site to explore racially problematic interventions related to food, as well as an arena to develop transformative alternatives. There is a long history in the field of education of blaming communities of color for their so-called underachievement in schools. This line of argument can be traced back to the 1965 Moynihan report, The Negro Family, which argued that "for the vast numbers of the unskilled, poorly educated [Black] city working class the fabric of conventional social relationships has all but disintegrated" (U.S. Department of Labor, Office of Policy Planning and Research, 1965, p. ii). This line of reasoning that identifies family structure as the reason for racial disparities in education became solidified as the "culture of poverty" argument over the next several decades; see the writings of Oscar Lewis for the origins of these ideas. The irony of the argument is clear: just as communities of color gained the right to equal educational opportunities, overcoming de jure segregation, white flight became legitimized as de facto segregation and communities of color in these newly segregated areas are now blamed for their educational inadequacies. This culture-of-poverty argument, along with a persistent belief in a color-blind ideology (Bonilla-Silva, 2006) in schools, masks the real reasons for educational disparities, namely, structural racism.

We argue that certain contemporary forms of food systems education fall into this same racist logic, assuming that school gardens and courses on nutrition are the key to improving the health and well-being of students of color. Nonetheless, we agree that more discussion about food systems in schools is a critical component of integrating youth into a collective struggle for more equitable food systems. Drawing on over six years of research with the Brazilian Landless Workers Movement (MST), we propose critical food systems education (CFSE) as an alternative to the "unbearable whiteness" of food systems education. The MST is one of the largest social movements in Latin America, with over 350,000 families that have addressed food insecurity and poverty through occupations of unproductive land estates that force the government to redistribute this land to these landless farmers (Branford \& Rocha 2002; Wolford, 2010). An alternative educational model is a central component of this struggle, as MST leaders have developed a series of organizational, curricular, and pedagogical initiatives that encourage youth to stay in the countryside and become peasant-intellectuals, helping to contribute to the sustainability of these new rural communities (Meek, 2015; Tarlau, in press). This educational struggle is in direct opposition to a racialized discourse of the "peasantry" as backwards, ignorant, and a soon-to-disappear segment of the population. The leaders of the MST reject the goal of education as producing "urban (white) modernity," and instead implement alterative educational programs that posit the peasantry as a political subject who can produce a more equitable food system, based in agroecological farming methods, in the twenty-first century Brazilian countryside.

Inspired by the MST's struggle in Brazil, we suggest the concept of critical food systems education (CFSE) as a theoretical framework, a set of 
pedagogies and pedagogical methods, and a vision for policy that can address the racialized narrative in U.S. and international food systems education. As a theoretical framework, CFSE incorporates insights from diverse theoretical traditions, such as critical pedagogy, food justice, agroecology, and food sovereignty. Critical pedagogy, grounded in the educational ideas of Paulo Freire (2002), defines education as a political project that is either actively maintaining or transforming the status quo. This suggests that the role of food systems education should be a dialectical process of analyzing the reality of the local food system, linking this local reality to national and international structures that have coproduced this local reality, and helping students come up with creative solutions to transform these realities: Freire's famous concept of praxis. The CFSE framework also draws on the lessons from food justice, a grassroots movement that is predicated upon a critique of the racial and classbased inequalities in the food system (Mares \& Alkon 2012). Food justice's attention to the structural racial and class-based inequality in the food system should be directed at transforming the neoliberal school food system, which increasingly consists of contingent labor, private-sector funding, and the delegation of responsibility to the local (Allen \& Guthman, 2006). Agroecology also plays an important role in critical forms of food systems education. CFSE engages with agroecology from a political perspective (de Molina, 2013); it focuses attention on the politics of agroecological knowledge, asking who is producing what knowledge and for what purposes? It also departs from the uncritical valorization of agroecological practices, asking students to consider how particular practices arose among particular marginalized communities, and the politics of appropriating them. Finally, food sovereignty, closely aligned with the political nature of agroecology, provides another major foundation for CFSE (Wittman, 2011). Food sovereignty is itself a global movement. Social movements fighting for food sovereignty, such as the MST and Via Campesina, have created their own educational institutions to train the next generation of movement leaders in political organizing and agroecological techniques (Rosset \& Martínez-Torres, 2012). Thus, as a component of CFSE, food sovereignty insists that food systems education be linked to these larger collective struggles.

In summary, critical food systems education (CFSE) is a tripartite perspective consisting of a theoretical framework, set of pedagogies, and vision for policy that posits food systems education as an inherently political and economic process that is mediated by racial and ethnic histories and identities, while also maintaining that these educational processes can be transformed to be a form of education for liberation. CFSE is directly relevant to questions concerning the intersection of race and the alternative food movement because it brings into question the larger project of food systems education and the motivations of its proponents. It calls us to explore how garden-based learning educators conceive of the subjects of their intervention and the subjectivities they seek to mold. As a transformative alternative, it also asks how educators in these programs can develop the critical consciousness to recognize and question their own racial assumptions, and engage with their students as cocreators of a transformative future. CFSE is not a new perspective, but rather builds on a long history of social movements incorporating education into their larger struggle against classism, racism, and sexism. Along with these social movements, we believe that "education either functions as an instrument which is used to facilitate integration of the younger generation into the logic of the present system and bring about conformity or it becomes the practice of freedom, the means by which men and women deal critically and creatively with reality and discover how to participate in the transformation of their world" (Freire, 2002, p. 34).

\section{References}

Alkon, A. H., \& McCullen, C. G. (2011). Whiteness and farmers markets: Performances, perpetuations... contestations? Antipode, 43(4), 937-959. http://dx.doi.org/10.1111/j.14678330.2010.00818.x

Allen, P., \& Guthman, J. (2006). From “old school” to "farm-to-school": Neoliberalization from the ground up. Agriculture and Human V alues 23(4), 401415. http://dx.doi.org/10.1007/s10460-006-9019-z 
An, R., \& Sturm, R. (2012). School and residential neighborhood food environment and diet among California youth. American Journal of Preventive Medicine, 42(2), 129-135. http://dx.doi.org/10.1016/j.amepre.2011.10.012

Anyon, J. (1997). Ghetto schooling: A political economy of urban educational reform. New York: Teachers College Press.

Boone-Heinonen, J., Gordon-Larsen, P., Kiefe, C. I., Shikany, J. M., Lewis, C. E., \& Popkin, B. M. (2011). Fast food restaurants and food stores: Longitudinal associations with diet in young to middle-aged adults: The CARDIA Study. JAMA Internal Medicine, 171(13), 1162-1170. http://dx.doi.org/10.1001/archinternmed.2011.283

Bonilla-Silva, E. (2006). Racism without racists: Color-blind racism and the persistence of racial inequality in America (2nd ed.). New York: Rowman \& Littlefield Publishers.

Bowles, S., \& Gintis, H. (1976). Schooling in capitalist America: Educational reform and the contradictions of economic life. London: Routledge \& Kegan Paul.

Branford, S., \& Rocha, J. (2002). Cutting the wire: The story of the landless movement in Brazil. London: Latin America Bureau.

de Molina, M. G. (2013). Agroecology and politics. How to get sustainability? About the necessity for a political agroecology. Agroecology and Sustainable Food Systems, 37(1), 45-59. http://dx.doi.org/10.1080/10440046.2012.705810

Etmanski, C. (2012). A critical race and class analysis of learning in the organic farming movement. Australian Journal of Adult Learning, 52(3), 484-506.

Freire, P. (2002). Pedagogy of the oppressed. New York: Continuum International Publishing.

Guthman, J. (2008). Bringing good food to others: Investigating the subjects of alternative food practice. Cultural Geographies, 15(4), 431-447. http://dx.doi.org/10.1177/1474474008094315

Guthman, J. (2012). Opening up the black box of the body in geographical obesity research: Toward a critical political ecology of fat. Annals of the Association of American Geographers, 102(5), 951-957. http://dx.doi.org/10.1080/00045608.2012.659635

Lee, H. (2012). The role of local food availability in explaining obesity risk among young school-aged children. Social Science and Medicine, 74(8), 11931203. http://dx.doi.org/10.1016/j.socscimed.2011.12.036
Lipman, P. (2011). The new political economy of urban education: Neoliberalism, race and the right to the city. New York: Routledge.

Mares, T. M., \& Alkon, A. H. (2012). Mapping the food movement: Inequality and neoliberalism. Environment and Society, 2, 68-86. http://dx.doi.org/10.3167/ares.2011.020105

Meek, D. (2015). Learning as territoriality: The political ecology of education in the Brazilian Landless Workers' Movement. Journal of Peasant Studies. Advance online publication. http://dx.doi.org/10.1080/03066150.2014.978299

Ramírez, M. M. (2015). The elusive inclusive: Black food geographies and racialized food spaces. Antipode, 47(3), 748-769. http://dx.doi.org/10.1111/anti.12131

Rosset, P. M., \& Martínez-Torres, M. E. (2012). Rural social movements and agroecology: Context, theory, and process. Ecology and Society, 17(3), Art. 17. http://dx.doi.org/10.5751/ES-05000$\underline{170317}$

Slocum, R. (2007). Whiteness, space and alternative food practice. Geoforum, 38(3), 520-533. http://dx.doi.org/10.1016/i.geoforum.2006.10.006

Tarlau, R. (in press). How do new critical pedagogies develop? Educational innovation, social change, and landless workers in Brazil. Teachers College Record.

U.S. Department of Labor, Office of Policy Planning and Research. (1965). The Negro family: The case for national action. Washington, D.C.: Author.

Waliczek, T. M., \& Zajicek, J. M. (1999). School gardening: Improving environmental attitudes of children through hands-on learning. Journal of Environmental Horticulture, 17(4), 180-184. http://hriresearch.theknowledgecenter.com/ Publications/index.cfm

Willis, P. (1977). Learning to labor: How working class kids get working class jobs. New York: Columbia University Press.

Wittman, H. (2011). Food sovereignty: A new rights framework for food and nature? Environment and Society: Advances in Research, 2(1), 87-105. http://dx.doi.org/10.3167/ares.2011.020106

Wolford, W. (2010). This land is ours now: Social mobilization and the meanings of land in Brazil. Durham, North Carolina: Duke University Press. http://dx.doi.org/10.1215/9780822391074 